\title{
TANGGUNGJAWAB NOTARIS PENGGANTI TERHADAP KESALAHAN AKTA OTENTIK YANG DIBUATNYA
}

\author{
Oleh : \\ Zakiah Noer", Ahmad Khoirul Khafid** \\ "Fakultas Hukum, Universitas Gresik \\ Email :Zakiahnoer12@gmail.com \\ ${ }^{* *}$ Fakultas Hukum Universitas Gresik \\ Email : Khoirulkhafid50@gmail.com
}

\begin{abstract}
ABSTRAK
Notaris Pengganti dalam menjalankan tugasnya memiliki wewenang, kewajiban dal larangan yang sama dengan Notaris. Salah satu kewenangannya adalah membuat akta otentik. Disaat pembuatan akta otentik, bukan tidak mungkin Notaris Pengganti melakukan kelalaian yang mengakibatkan terjadinya kesalahan dalam pembuatan akta. Hukum Notaris Pengganti meliputi tanggungjawab secara administrasi, tanggung jawab secara perdata dan tanggungjawab secara pidana. Adapun akibat yang ditimbulkan karena terjadinya kesalahan dalam pembuatan akta yaitu akta tersebut mempunyai kekuatan pembuktian dibawah tangan atau batal demi hukum. Dimana apabila para pihak yang membuat akta tersebut menderita kerugian, maka dapat menjadi alasan bagi para pihak untuk meminta ganti rugi kepada Notaris Pengganti. Ketika hal tersebut terjadi, maka yang harus bertanggung jawab atas kerugian yang diderita oleh para pihak didalam aktaadalah Notaris Pengganti. Karena didalam UUJN Notaris Pengganti sudah diberikan kewenangan, kewajiban dan larangan yang sama seperti Notaris, sehingga kedudukan Notaris dan Notaris Pengganti adalah sama. Hanya saja Notaris Pengganti menjalankan tugasnya dibatasi oleh waktu sesuai dengan surat pengangkatannya, yakni pada saat Notaris menjalankan cuti. Notaris Pengganti bertanggungjawab terhadap akta yang dibuatnya pada saat masih menjabat maupun sudah tidak menjabat. Dengan kata lain sifatya melekat sepenuhnya kepada Notaris Pengganti. Tanggungjawab.
\end{abstract}

Kata kunci; Akta; Notaris Pengganti; Kewenangan; Tanggungjawab.

\section{PENDAHULUAN}

Kepastian hukum pada hal pelayanan jasa sangat dibutuhkan pada masyarakat yang berkembang, semakin meningkatnyam permintaan terhadap kepastian hukum dalam beraneka ragam hubungan maka pembutuhan terhadap pembuktian tertulis berbentuk suatu akta otentik akan meningkat. Notaris ialahpejabat umum yang dilantik pemerintah untuk memenuhi kebutuhan masyarakat dalam membuat perjanjian. Ketika melaksanakan suatu tugas, baik tugas jabatan ataupun tugas profesi, setiap pelaksanaannya membutuhkan tanggungjawab dari seseorang yang melaksanakan tugas tersebut. Ketika melaksanakan tugasnya, terkadang seseorang sudah melakukan tugasnya dengan sebaik- baiknya.

Namun karena kurangnya pengetahuan ataupun kurangnya pengalaman dalam menjalankan tugasnya terkadang seseorang 
tanpa sengaja melalikan kewajiban dan tanggung jawab atas tugasnya. Ketika melaksanakan suatu profesi dapat terjadi kesalahan dikarenakan kurangnya pengetahuan atau ketidaktahuan, kurang pengalamanatau kurangnya jam terbang, atau kurangnya pengertian. Notaris merupakan pejabat umum yang mempunyai wewenang membuat akta otentik dan memiliki kewenangan lainnya sebagaimana diatur dalam UUJN atau berdasarkan Undang-undang lainnya. "Jabatan Notaris diadakan atau kehadirannya dikehendaki oleh aturan hukumdengan maksud untuk membantu dan melayani masyarakat yang membutuhkan alat bukti tertulis yang bersifat otentik mengenai keadaan, peristiwa atau perbuatan hukum"1 bertanggung jawab kepada dirinya sendiri dan kepada masyarakat. Tanggungjawab Notaris Pengganti meliputi tanggungjawab secaraadministrasi, tanggungjawab secara perdata dan tanggungjawab secara pidana. Didalam penelitian ini bertujuan untuk mengetahui bagaimana bentuk pertanggung jawaban Notaris Pengganti terhadap kesalahan akta otentik yang dibuatnya dan kekuatan akta otentik yang ditibulkan jika terjadi kesalahan dalam pembuatan akta otentik olehNotaris Pengganti.

\section{METODE PENELITIAN}

Jenis penelitian hukum yang digunakan penulis adalah penelitian hukum Normatif normative legal research yaitu penelitian hukum untuk

\footnotetext{
${ }^{1}$ Habib Adjie, Sanksi Perdata dan Administratif Notaris Sebagai Pejabat
}

menemuakan aturan hukum, prinsip-prinsip hukum, maupun doktrin-doktrin hukum guna menjawab isu hukum yang dihadapi. Adapun metode pendekatan yangdigunakan adalah metode pendekatan Undangundang statute approach pendekatan konseptual conceptual approach, dan pendekatan perbandingan comparative approach.

\section{PEMBAHASAN}

Berdasarkan Pasal 1 Nomer (1) UUJN Notaris merupakan pejabat umum yang mempunyai wewenang membuat akta otentik serta memiliki wewenang yang lain sebagaimana dijelaskan dalam UUJN atau sebagaimana dimaksud dalam aturan lainya.

Dalam menjalankan tugasnya, Notaris berpedoman kepada UUJN. Didalam aturan tersebut juga disebutkan sanksi yang diterima notaris jika melanggar aturan yang ada. Dengan adanya UUJN dan UUJN diharapkan menjadi pedoman yang teguh dalam menjalankan tugasnya sebagai notaris. Dalam melaksanakan tugasnya, notaris juga berpedoman kepada kode etik notaris, hal ini dijelaskan dalam Pasal 83 Nomer (1) UUJN yang menegaskan bahwa organisasi notaris menetapkan dan menegakkan kode etik notaris.

Wewenang yang diperoleh suatu jabatan mempunyai suber asalnya. "Dalam hukum administrasi wewenang bisa

Publik, Reflika Aditama, Surabaya, 2013, h.32 
diperoleh secara Atribusi, Delegasi, atau Mandat."

1. Atribusi merupakan pelimpahan wewenang yang baru kepada suatu jabatan berlandasan suatu aturan perundang-undangan atau peraturan hukum

2. Delegasi merupakan pemindahan/

pengalihan wewenang yang ada berdasarkan suatu peraturan perundangundangan atau aturan hukum.

3. Mandat sebenarnya bukan pengalihan atau perpindahan wewenang, melainkan karena yang berkompeten berhalangan

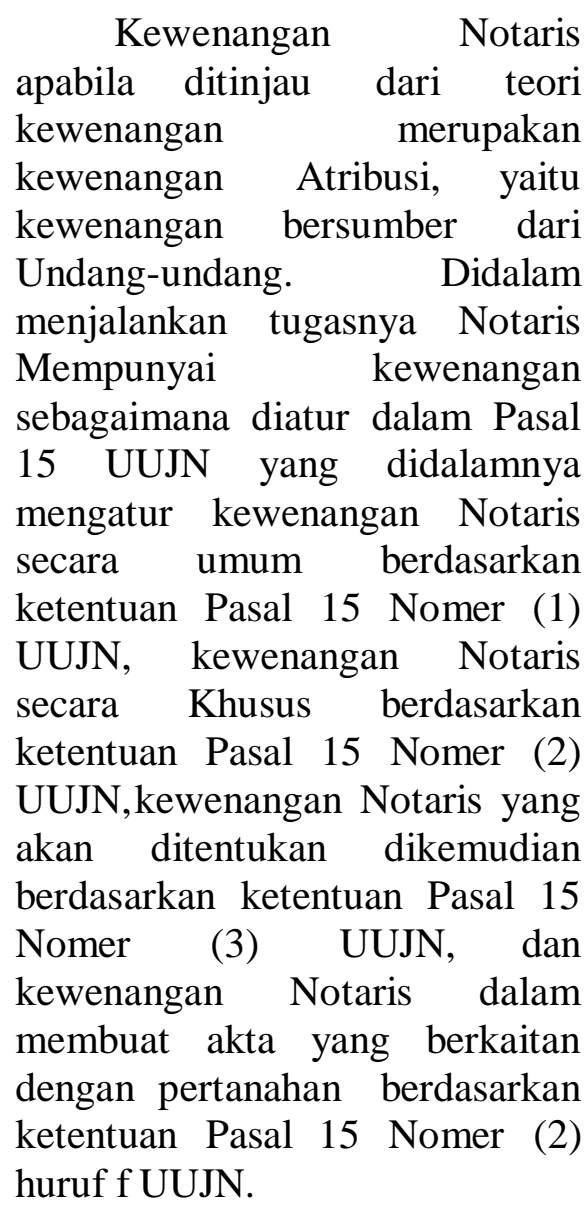

${ }^{2}$ Habib Adjie, Hukum Notaris Indonesia Tafsir Tematik Terhadap UU No. 30 Tahun 2004 Tentang Jabatan
Pada Pasal 25 UUJN, Dalam menjalankan tugasnya Notaris mempunyai hak untuk mengajukan cuti. Notaris dapat mengajukan permohonan cuti ketika sudah menjalankan masa jabatannya selama lebih dari 24 bulan. Disebutkan pada Pasal 27 Nomer (2) Surat permohonan cuti diajukan kepada pejabat yang berwenang dalam halini Majelis Pengawas Notaris dengan menunjuk Notaris Pengganti.

Notaris

Pengganti merupakan seseorang yang sementara waktu diangkat atau dilantik oleh pejabat yang berwenang untuk dijadikan Notaris sementara, agar fungsi pelayanan Notaris kepada masyarakat tidak terganggu dalam hal pelayanan pembuatan perjanjian dalam bentuk akta Notaris. Adapun Notaris dalam mengambil cuti dapat beralasan sakit atau dalam keadaan mendesak untuk sementara tidak dapat menjalankan tugasnya sebagai Notaris. Kewenangan Notaris dalam hal membuat akta terdapat pada Pasal 1 huruf a UUJN yaitu membuat akta otentik.

Menurut Pasal 1 Nomer (3) berkaitan dengan pasal 33 Nomer (2) dimaksudkan untuk mengatur kedudukan Notaris Pengganti yakni sebagai Notaris. Notaris Pengganti dalam menjalankan tugasnya mempunyai kewenangan, kewajiban serta larangan yang sama sepertiNotaris. Dengan kedudukan demikian, maka Notaris Pengganti merupakan pejabat umum yang dimaksud pada Pasal 1868 KUHPerdata. sehingga dapat

Notaris, Cet. IV, Refika Aditama, Surabaya, 2014, h.77 
dikatakan bahwa dalam membuat akta otentik Notaris Pengganti memiliki kewenangan yang sama seperti Notaris serta akta tersebut memiliki kekuatan pembuktian yang sempurna seperti akta yang dibuat Notaris.

Setiap kewenangan harus ada dasar hukumnya. Mengenai wewenang, seorang pejabat apapun harus jelas dalam peraturan perundang-undangan yang mengantur tentang jabatan tersebut. Sehingga jika seseorang pejabat melakukan perbuatan yang diluar kewenangannya sebagai mana yang dimaksud didalam peraturan perundangundangan,sehingga dapat dikatakan pejabat tersebut melakukan tindakan melanggar hukum, yaitu dengan melakukan sesuatu diluar kewenangannya. Oleh karena itu kewenangan tidak hanya muncul melalui suatu diskusi atau perbincangan di belakang meja ataupun karena pembahasan- pembahasan atau pendapat-pendapat lembaga legeslatif, melainkankewenangan itu harus dinyatakandengan tegas dalam aturan yang sesuai dengan yang bersangkutan.

Kewenangan yang diperoleh Notaris Pengganti berdasarkan teori kewenangan merupakan kewenangan delegasi yaitu kewenangan yang bersumber dari pelimpahan suatu organ pemerintahan kepada organ yang lain dengan dasar peraturan perundang-undagan. Dalam hal ini dari Notaris kepada Notaris Pengganti yang berdasarkan UUJN. maka akta yang dibuat oleh Notaris Pengganti memiliki kekuatan yang sama dengan akta yang dibuat oleh Notaris.
Berdasarkan Pasal 1866 KUHPer menyatakan bahwa bukti tulisan ialah salah satu alat bukti tertulis. Kegunaan akta Notaris memiliki suatu peranan yang penting baik digunakan sebagai alat bukti atau digunakan sebagai syarat sahnya suatu perjanjian Hukum. Suatu akta otentik mempunyai peranan yang sangat penting sebagai alat bukti bagipara pihak yang melakukan perjanjian sehinggan akta otentik harus mempunyai kekuatan pembuktian yang sempurna. Keotentikan yang dimaksud harus sesuai dengan peraturan yang ada dalam Undangundang. Bukan hanya pada kertasnya saja.

Adapun didalam Pasal 1868 KUHPer memberikan batasan mengenai unsur-unsur yang dimaksud dengan akta otentik adalahakta itu wajib sesuai dengan peraturan perundang-undangan dan dibentuk oleh/dihadapan pejabat umum mempunyai wewenang tersebut.

Akta Notaris terdiri dari:

1. Akta yang dibentuk oleh Notaris, atau bisa disebut dengan dengan istilah Akta Relaas ataupun Berita Acara

2. Akta yang dibentuk dihadapan Notaris, atau biasa disebut dengan istilah Akta Pihak atau Akta Partij. 
Pembuatan akta relaas dan partij yang menjadi dasar atau inti dalam membuat suatu akta otentik, yaitu dengan adanya kehendak atau permintaaan dari para pihak yang membuat akta otentik. Notaris tidak akan bisa membuat akta apabila tidak ada keinginan atau kehendak para pihak. Hal ini sesuai dengan Pasal 38 Nomer (3) huruf c UUJN yang menatakan bahwa isi akta merupakankehendak para pihak yang berkepentingan, dengan kata lain isi akta merupakan kehendak atau keinginan para pihak itu sendiri, bukan kehendak atau keinginan dari Notaris, namun Notaris tetap membatasinya dalam bentuk aktaNotaris sesuai dengan UUJN. Sehingga isi akta tersebut tidak menyalahi aturan yang ada padaUUJN.

Di dalam Pasal 38 Nomer (3) huruf c UUJN menyatakan bahwa isi akta yang merupakan kehendak dan keinginan dari pihak yang berkepentingan, dengan kata lain isi akta tersbut adalah kehendak atau keinginan para penghadap sendiri, bukan kehendak atau keinginan dari Notaris, namun Notaris tetap membingkainya dalam bentuk akta Notaris sesuai dengan UUJN. Sehingga dalam akta tesebut tidak menyalahi aturan atau larangan didalam UUJN. Yang terpenting dalam pemuatan akta adalah penandatanganannya, dengan menandatangani suatu adalah suatu akta seseorang diangap menanggung atas kebenaranapa yang ditulis di dalam akta tersebut. Sesuai dengan Pasal 16Nomer (1) bahwa akta yang termuat pada akta telah dimengerti oleh para pihak sesuai dengan keinginan para pihak, yakni dengan cara membacakannya sehingga menjadijelas.

Didalam Pasal 51 Nomer (1)UUJN menyebutkan bahwa Notaris juga berwenang untuk membetulkan kesalahan tulis dan/atau kesalahan ketik yang terdapat pada minuta akta yang telah ditandatangani. Pembetulan yang dimaksud sesuai dengan Pasal 51 Nomer (2) UUJN harus dilakukan dihadapan saksi, penghadap dan Notaris yang dituangkan dalam berita acara dan memberi catatan tentang hal tersebut pada minuta akta asli . Hal ini sesuai dengan Pasal 51 Nomer (3) UUJN berita acara tersebut wajib disampaikan kepada para pihak. Apabila terjadi kesalahan dalam pembuatan akta sebelum akta ditandatangani menurut Pasal 48 Nomer (2) UUJN menerangkan bahwasanya perubahan atas akta berupa penambahan, penggantian, atau pencoretan didalam akta dikatakan sah dengan persyaratan yang sudah ditentukan UUJN yakni perubahan akta tersebut diparaf atau diberi pengesahan lain oleh penghadap, saksi, dan Notaris. “...perubahan tersebut dalam dunia Notaris disebut renvoi. ${ }^{3}$

Ketika dalam akta terjadi kesalahan dalam pengetikan dan dilakukan renvoi atau perubahan oleh Notaris dan para pihak dalam aktatidak mengetahui adanya perubahan atau renvoi maka ini suatu pelanggaran. Pelanggaran atas peraturan mengenai perubahan isi akta atau renvoi mengakibatkan akta hanya mempunyai kekuatan pembuktian sebagai akta dibawah tangan dan dapat dijadikan alasan bagi para pihak untuk menuntut penggantian biaya, ganti rugi, dan bunga kepada Notaris.

Ketika akta tersebut sudah ditandatangani berdasarkan Pasal 51 Nomer (1) UUJN menyatakan bahwa Notaris mempunyai kewenangan membetulkan kesalahan tulis dan/atau kesalahan ketik yang terdapat pada minuta akta yang telah ditandatangani. Pembetulan akta yang sudah ditandatangani ini dilakukan sesuai dengan Pasal 51 Nomer (2) UUJN yakni. Dan Salinan berita acara pembetulan disampaikan kepada para pihak, hal ini sesuai dengan Pasal 51 Nomer (3) UUJN. Adapun didalam akta terdapat suatu perjanjian yang dilakukan para pihak. Syarat sahnya suatu perjanjian dalam Pasal 1320 KUH Perdata yaitu: sepakat

3 Oeman Moechthar, Dasar-dasar Teknik Pembuatan Akta, Airlangga University Press, Surabaya, 2017, h.99 
mereka yang mengikatdirinya,kecakapan dalam suatuperikatan, suatu hal tertentu, dan suatu sebab yang halal.

Dari empat syarat diatas, syarat sepakat dan kecakapan dalam suatu perikatan merupakan syarat subjektif karena mengenai subjeknya yang melakukan perjanjian. Sedangkan syarat mengenai suatu hal tertentu dan suatu sebab halal merupakan syarat objektif, karena mengenai objek dari perbuatan hukum yang dilakukan.

$$
\text { Didalam Pasal } 1869
$$

KUHPerdata menjelaskan bahwa Akta Notaris yang mempunyai kekuatan pembuktian dibawah tangan dapat terjadi dengan alasan tidak terpenuhinya ketentuan - ketentuan didalam Undangundang, karena akta tersebut tidak dibuat oleh pejabat yang berwenang, tidak bisanya pejabat umum yangbersangkutan, ataupun cacat dalam bentuknya. Bisa disebut juga tidak terpenuhinya syarat subjektif suatu akta. Ketika akta tersebut sudah ditandatangani oleh para pihak maka akta tersebut tetap memiliki kekuatan pembuktian sebagai akta dibawah tangan.

Sanksi perdata jika Notaris melakukan perbuatan melawan hukum atau pelanggaran terhadap Pasal 38, Pasal 39 dan Pasal 40 UUJN diatur dalam Pasal 41 UUJN, maka akta tersebut hanya mempunyai pembuktian sebagai akta dibawah tangan. Adapun jika terjadi kesalahan dalam akta yang diuat oleh Notaris atau Notaris Pengganti karena tidak sesuai dengan peraturan perundangundangan maka para pihak yang menderita kerugian dapat meminta ganti rugi.

Mengenai akta batal demihukum
seorang Notaris membuat akta
berdasarkan kehendak dan keinginan para
pihak penghadap yang datang dihadapan
Notaris halini sesuai dengan ketentuan
Pasal 36 Nomer (3) huruf c UUJN. Ketika
terdapat syarat objektif yang terdapat

${ }^{4}$ Habib Adjie, Kebatalan Dan Pembatalan Akta Notaris, Refika Aditama, Surabaya, 2017, h.67 dalam akta tidak dipenuhi oleh salah Ketika dalam membuat akta syarat-syarat yang sudah ditentukan oleh hukum tidak terpenuhi, maka tanpa melakukan tindakan hukumtertentu dari para pihak yang bersangkutan dan/ atau yang berkepentingan secara otomatis akta tersebut menjadi batal demi hukum atau mempunyai kekuatanpembuktian sebagai akta dibawah tangan. "Oleh karenanya, kebatalan tersebut bersifat pasif, yang artinyaapabila tanpa ada tindakan aktif ataupun upaya apapun parapihak yang terlibat dalam suatu perjanjian, maka akan batal ataubatal demi hukum karena ada syarat- syarat yang tidak terpenuhi". ${ }^{4}$

Adapun sanksi yang ada dalam UUJN, menjelaskan bahwa tindakan pelanggaran yang dilakukan Notaris terhadap peraturan sebagaimana yang dimaksud dalam beberapa Pasal, jika terjadi kesalahan salah satu pasal yang ada dilanggar, maka terjadi perbuatan yang melanggarhukum, sehingga terdapat unsurperbuatan melanggar hukum sudah ada. Maka, bagi para pihak yang menderita kerugian dapat menuntut penggantian biaya, ganti rugi dan bunga kepada Notaris ataupun Notaris Pengganti. Dalam pemberian sanksi administrasi merupakan pengawasan dan penegasan sanksi, pengawasan merupakan langkah represif untuk memaksakan kepatuhan. Dalam menegakkan sanksi administrasi kepada Notaris Pengganti yang menjadi instrumen adalah majelispengawas yang mengambil langkah- langkah proventif.dalam pemberian sanksi administrasi kepada Notaris Mengenai tanggungjawab Hukum secara Administrasi yang diterima oleh Notaris maupun Notaris Pengganti apabila melakukan kesalahan maka dapat dijatuhi sanksi berupa

1. Teguran secara lisan,

2. Teguran secara tertulis,

3. Pemberhentian sementara,

4. Pemberhentian secara hormat, 
5. pemberhentian secara tidakhormat.

Adapun penjelasan lebih lanjut dalam keadaan dimana Notaris atau Notaris Pengganti akan diberikan sanksi dengan sebagaimana disebutkan dalam pasal 16 Nomer (11) UUJN. Mengenai Sanksi Hukum Administrasi terhadap Notaris atau Notaris. Pengganti karena

kesalahannya dalam membuat akta otentik disebutkan pasal 16 Nomer (11) UUJN menyangkut ketentuan sebagaimana dimaksud dalam beberapa pasal dalam UUJN.

"Sanksi Notaris yang didapat karena melanggar ketentuan-ketentuan sebagaimana yang disebutkan dalam Pasal 85 UUJN merupakan Sanksi Internal, yaitu sanksi terhadap Notaris dalam melaksanakan tugas jabatannya tidak melakukan serangkaian tindakan tertib pelaksanaan tugas jabatan kerja satu pihak maka akta menjadi batal demi hokum Notaris yang harus dilakukan untukkepentingan Notaris sendiri." 5

$$
\text { Berkaitan dengan }
$$

keperdataan yakni mengenai perikatan yang dibuat oleh beberapa pihak yang diikat oleh Notaris maupun Notaris Pengganti walaupun memungkinkan dibuat secara sepihak. Seperti yang dijelaskan pada Pasal 16 Nomer (11) UUJN, bahwa tindakan pelanggaran yang dilakukan oleh Notaris terhadapketentuan yang dimaksudkan beberapa Pasal, maka jika salah satu pasal tersebut dilanggar maka sudah terjadi perbuatan melanggar hukum.

Pasal 16 Nomer (12) UUJN menyatakan bahwa dapat menjadi alasan bagi para pihak yang rugi untuk menuntut biaya ganti rugi dan bunga kepada Notaris. Apabila akta yang diterbitkan Notaris tidak sepertiketentuan yang ada didalam aturan yang ada, maka akta itu akan keotentikannya akan hilang dan akta tersebut akan batal. Cacatnya karena kesalahan suatu akta otentik yang dapat menyebabkan Notaris bertanggung jawab

\footnotetext{
${ }^{5}$ Habib Adjie, Sanksi Perdata Dan Administratif Terhadap Notaris Sebagai Pejabat
}

dan akan dikenai sanksi berupa ganti rugi yang telah dialami para pihak karena kesalahan aktayang dibuatnya. Berkaitan dengan pertanggung jawaban Notaris Pengganti secara pidana terhadap akta yang diterbitkan tidak diatur didalam UUJN namun pertanggung jawaban Notaris Pengganti secara pidana dapat dikenakan apabila Notaris Pengganti melakukan perbuatan tidak pidana. Di dalam Pasal 38 Nomer (3) huruf c UUJN menyatakan bahwa isi akta yang merupakan kehendak dan keinginan dari pihak yang berkepentingan, dengan kata lain isi akta tersbut adalah kehendak atau keinginan para penghadap sendiri, bukan kehendak atau keinginan dari Notaris. Mengenai isi akta Notaris Pengganti yang membuat akta tidak dapat dimintai tanggung jawab,karena Notaris Pengganti hanya menuangkan apa yang disampaikan kepada para pihak yang membuat akta untuk dituangkan ke dalam akta Otentik. Contoh Pasal-pasal yang dapat dibuat untuk menuntut Notaris Pengganti ketika menjalankan jabatannya adalah Pasalpasal yang mengatur mengenai tindak pidana Pemalsuan surat.

Pertanggungjawaban secara pidana Notaris Pengganti terhadap kebenaran materiil dalam akta aturan dibuatnya dapat ditelusuri dari pemahaman akta tersebut. Sanksi Pidana kepada Notaris dilihat dalam rangka jabatannya sebagai Notaris, artinya dalam perbuatan atau prosedur pembuatan akta harus berdasarkan kepada aturan hukum yang mengatur hal tersebut, dalam hal ini UUJN. Menimbang bahwa Notaris dan Notaris Pengganti mempunyai kedudukan yang sama maka seperti Notaris, penjatuhan sanksi pidana kepada Notaris Pengganti sama dengan sanksi pidana kepada Notaris yakni apabila dilakukan sepanjang batasan-batasan yang ada pada peraturan perundang- undangan tersebut telah dilanggar.

Apabila terjadi tindakan pelanggaran ataupun perbuatan melawan

Publik, Cet. III, Refika Aditama, Surabaya, 2013, h. 114 
hukum yang dilakukan UUJN suatu pelanggaran, maka Notaris tersebuttidak bisa dijatuhi hukuman pidana, karena ukuran untuk menilai sebuah akta harus berdasarkan kepada UUJNdan kode etik jabatan Notaris. Notaris Pengganti memiliki tanggungjawab yang sama dengan Notaris yang digantikannya dalam pembuatan akta otentik hal ini sesuai dengan Pasal 65 UUJN. Fungsi yang dimiliki oleh Notaris Pengganti tidak ada perbedaan dalam hal kewenangan dan tanggungjawab terkait fungsi sebagai Notaris, karena berdasarkan Pasal 33 Nomer (2) UUJN, Notaris Pengganti hanya menggantikan Notaris selama menjalankan cuti. Berkaitan dengan sampai kapan pertanggung jawaban Notaris Pengganti tehadap akta otentik yang dibuatnya adalah seumur hidup. Tanggungjawab hukum Notaris Pengganti Terhadap kesalahan akta otentik yang dibuatnya sepenuhnyaberada pada Notaris Pengganti baik ketika masih menjabat ataupun sudah tidak menjabat.Walaupun pada saat masa jabatannya sudah habis dan Notaris

Pengganti wajibmengembalikan jabatan dan potokolnya kepada Notaris yang digantikannya. Namun jika terdapat kesalahan akta yang dibuatnya pada saat masih menjabat.setelah masa jabatannya beakhir, maka secara individu Notaris Pengganti tetap dapat dimintai pertanggungjawaban terhadap kesalahan akta yang dibuatnya Notaris sudah memenuhi suatu tindak pidana.

\section{PENUTUP}

\section{KESIMPULAN}

Tanggungjawab hukum Notaris Pengganti Terhadap kesalahan aktaotentik yang dibuatnya sepenuhnya berada pada Notaris Pengganti baik pada saat masih menjabat ataupun sudah tidak menjabat. Karenakedudukan Notaris Pengganti yang sama persis dengan Notaris yang digantikannya. Hal ini sesuai dengan ketentuan Pasal UUJN yang menyatakan bahwa kewenangan, larangan yang berlaku pada Notaris berlaku juga pada
Notaris Pengganti yang menggantikannya pada saat Notaris sedang cuti. Adapun akibat akta yang terjadi jika akta Notaris Pengganti melakukan kesalahan dalam pembuatan akta yaitu akta tersebut mempunyai kekuatanpembuktian dibawah tangan atau batal demi hukum.

\section{SARAN}

Notaris Pengganti supaya dalam menjalankan kewenangan sebagai pembuat akta otentik dengan hati-hati dan megikuti peraturan perundang-undangan yang ada.Karena dalam akta otentik berisi perjanjian para pihak yang didalamnya harus memiliki kekuatan pembuktian yang sempurna. Sehingga dapat mengurangi resiko terjadinya kerugian oleh para pihak yang membuat perjanjian, yang dapat menjadi alasan bagi para pihak untuk menuntut penggantian biaya, ganti rugi, dan bunga kepada sipembuat akta otentik, dalam hal ini Notaris ataupun Notaris Pengganti.

\section{DAFTAR PUSTAKA}

Adjie, Habib, Sanksi Perdata dan Administratif Terhadap

Notaris Sebagai Pejabat Publik, Refika Aditama, Surabaya, 2013.

Adjie, Habib, Hukum Notaris Indonesia Tafsir TematikTerhadap UU No. 30 Tahun 2004 Tentang Jabatan Notaris, Refika Aditama, Surabaya, 2014.

Adjie, Habib, Kebatalan dan Pembatalan Akta Notaris, Refika Aditama, Surabaya, 2017.

Moechthar, Oemar, Dasar-dasar Teknik Pembuatan Akta, Airlangga University Press, Surabaya, 2017 